\begin{tabular}{|c|l|}
\hline Title & $\begin{array}{l}\text { Temperature Confining Pressure Coupling Effects on the Permeability of Three Rock types under Triaxial } \\
\text { Compression }\end{array}$ \\
\hline Author(s) & A lam A.K.M., Badrul; Fujii, Y oshiaki; Fukuda, Daisuke; Niioka, Masaki \\
\hline Citation & Rock Engineering and Rock Mechanics: Structures in and on Rock Masses, ISBN: 978-1-13800-149-7, 131-136 \\
\hline Issue Date & 2014 05 \\
\hline Doc URL & http:/hdl.handle.net/2115/58549 \\
\hline Type & proceedings (author version) \\
\hline Note & 2014 ISRM European Rock Mechanics Symposium (EUROCK 2014), May 27-29, 2014, Vigo, Spain. \\
\hline File Information & EUROCK 2014.131-136.pdf \\
\hline
\end{tabular}

Instructions for use 


\title{
Temperature-confining pressure coupling effects on the permeability of three rock types under triaxial compression
}

\author{
A.K.M.B. Alam, Y. Fujii \& D. Fukuda \\ Rock Mechanics Laboratory, Sustainable Resources Engineering, Hokkaido University, Sapporo, Japan
}

M. Niioka

Mitsubishi Corporation Exploration, Tokyo, Japan

\begin{abstract}
Triaxial compression tests were carried out at 295K and 353K under confining pressure of 1-15 MPa for Shikotsu welded tuff, Kimachi sandstone and Inada granite. The samples were kept for $24 \mathrm{hr}$ consolidation and then axial compression was applied measuring permeability. Permeability decreased monotonously for Shikotsu welded tuff. The permeability decreased first, began to increase before peak load and showed almost constant value in the residual strength state for Kimachi sandstone and Inada granite. Permeability decreased by failure for Shikotsu welded tuff. It increased due to failure under low confining pressures but decreased under high confining pressures for Kimachi sandstone. It increased due to failure for Inada granite. The permeability at $353 \mathrm{~K}$ was lower than that at $295 \mathrm{~K}$ for all of the three types of rock. The mechanisms of the permeability decrease are also shown.
\end{abstract}

\section{INTRODUCTION}

Stress redistribution and change in permeability happen within the Excavation disturbed Zone (EdZ) and Excavation Damaged Zone (EDZ). This puts significant impacts on short- as well as long-term stability of excavations as Hydro Mechanical (HM) processes. The EDZ can be under low or relatively high confining pressure (Fig. 1) and temperature change in rock mass

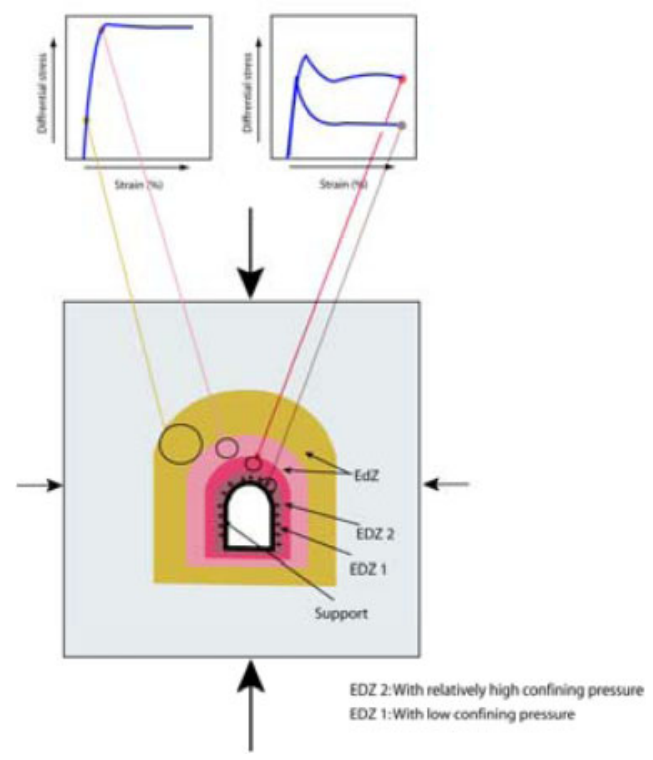

Figure 1. EdZ and EDZ around an underground excavation. which significantly affects the sealability and permeability of radioactive waste repositories (Hudson et al. 2005, Rutqvist et al. 2005) can be introduced either by human activities or by natural processes. The objective of this research is to know the influences of temperature-confining pressure coupling on permeability as Thermo Hydro Mechanical (THM) processes.

\section{MATERIALS AND METHODS}

Three rock types were considered for the experiments. (i) Shikotsu welded tuff: highest effective porosity of $37 \%$ with low UCSS (saturated uniaxial compressive strength) of $14 \mathrm{MPa}$. (ii) Kimchi sandstone: $19 \%$ effective porosity with UCSS of $21 \mathrm{MPa}$. (iii) Inada granite: low effective porosity of $0.6 \%$ with UCSS of $181 \mathrm{MPa}$.

The ultra compact triaxial cell (Fig. 2, Alam et al. 2014) which was covered with a heater to maintain target temperature (295K and $353 \mathrm{~K}$ ) was used for the experiments. The lower attachment was connected to the syringe pump. The upper attachment was opened to the atmosphere in constant flow method or attached to a reservoir for transient pulse method to measure permeability.

24 hours consolidation was carried out under target consolidation pressure and temperature for each specimen. Afterward, constant strain rate compression at $10^{-5} \mathrm{~s}^{-1}(0.036 \mathrm{~mm} / \mathrm{min})$ was applied on the consolidated samples. The compression was continued until the stroke based axial strain reached at $10 \%$ for Shikotsu welded tuff measuring permeability by 


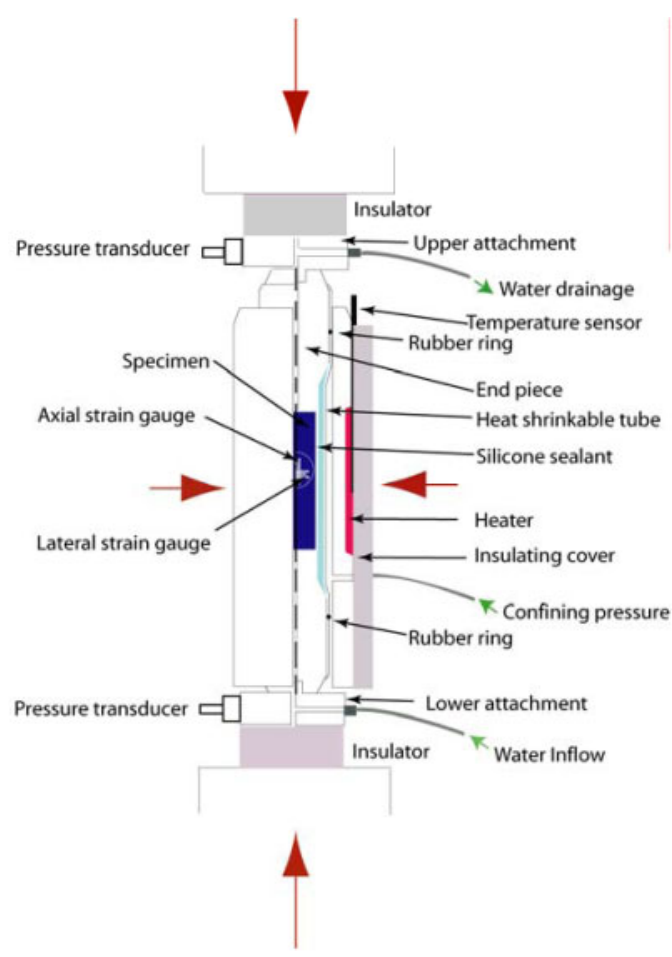

Figure 2. Ultra compact triaxial cell with heater. Showing water inflow and water drainage during constant flow method.
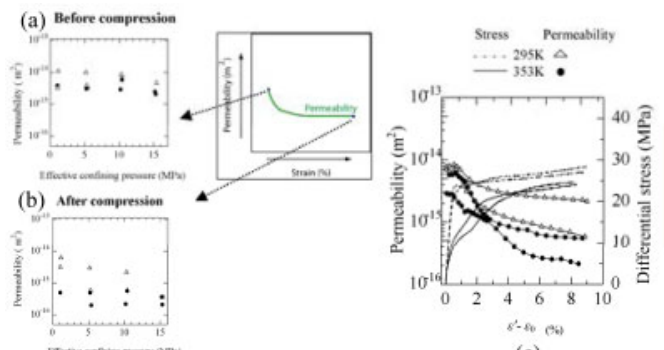

(c)

Figure 3. Permeability of Shikotsu welded tuff.

constant flow method or 7\% for Kimachi sandstone and Inada granite measuring permeability by transient pulse method. Data sampling interval was $10 \mathrm{~s}$.

\section{RESULTS AND DISCUSSION}

\subsection{Shikotsu welded tuff}

After 24 hours of consolidation, the permeability at $295 \mathrm{~K}$ was higher than the permeability at $353 \mathrm{~K}$ (Fig. 3a) and permeability under $15 \mathrm{MPa}$ confining pressure $\left(P_{\mathrm{c}}\right)$ was the lowest. Permeability decreased monotonously during compression (Fig. 3c). The post compression permeability at $295 \mathrm{~K}$ decreased with confining pressure (Fig. 3b). On the other hand, it was

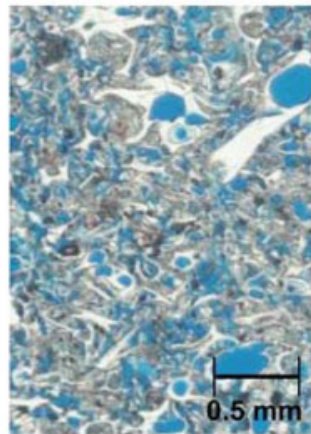

Fresh specimen

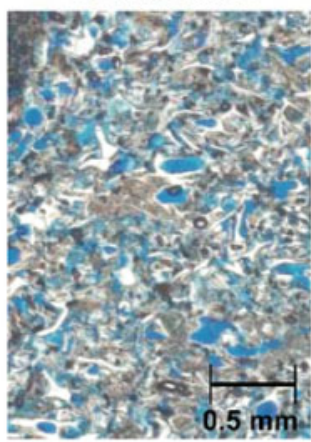

$15 \mathrm{MPa} 295 \mathrm{~K}$

(a)

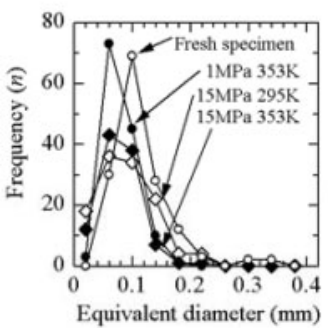

(b)

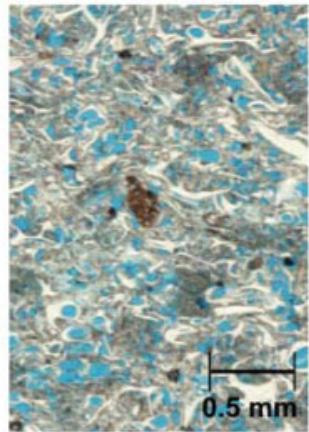

$1 \mathrm{MPa} 353 \mathrm{~K}$

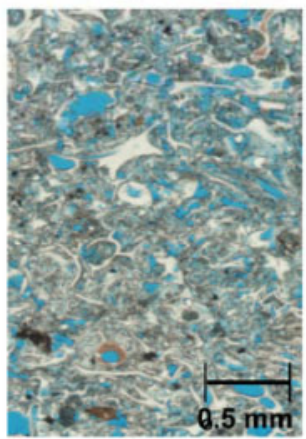

$15 \mathrm{MPa} 353 \mathrm{~K}$

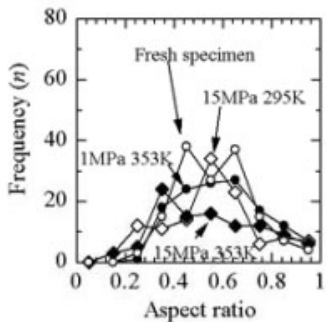

(c)

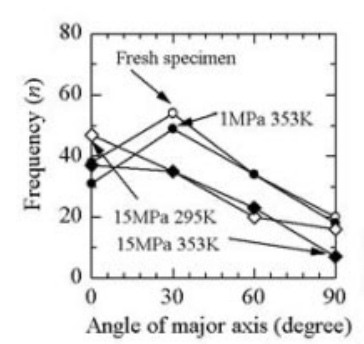

(d)

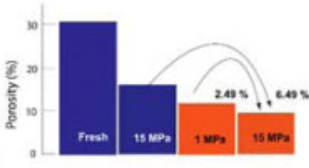

(e)
Figure 4. Thin section image and analyses of consolidated specimens of Shikotsu welded tuff.

almost independent of confining pressure at $353 \mathrm{~K}$ and as low as that under $15 \mathrm{MPa} P_{\mathrm{c}}$ at $295 \mathrm{~K}$.

In the thin section image analyses of 24 hours consolidated specimen (Fig. 4a), the porosity decreased by $2.49 \%$ from $1 \mathrm{MPa}$ to $15 \mathrm{MPa} P_{\mathrm{c}}$ at $353 \mathrm{~K}$ and 
$6.49 \%$ from $295 \mathrm{~K}$ to $353 \mathrm{~K}$ under $15 \mathrm{MPa} P_{c}$ (Fig. $4 \mathrm{e}$ ). $0.10 \mathrm{~mm}$ equivalent diameter pores were dominant for fresh specimen whereas $0.06 \mathrm{~mm}$ equivalent diameter pores were dominant at $353 \mathrm{~K}$. Significant decrease of $0.14 \mathrm{~mm}$ from $295 \mathrm{~K}$ to $353 \mathrm{~K}$ under $15 \mathrm{MPa} P_{\mathrm{c}}$ (Fig. 4b) was observed. The frequency of pores having aspect ratio of $0.45-0.65$ which was dominant under $1 \mathrm{MPa} P_{\mathrm{c}}$ at $353 \mathrm{~K}$ decreased under $15 \mathrm{MPa} P_{c}$ (Fig. $4 \mathrm{c}$ ). Pores parallel to the horizontal flow layer still dominated at $15 \mathrm{MPa} P_{\mathrm{c}}$ (Fig. $4 \mathrm{~d}$ ).

In CT images of post compression specimens, main rupture plane with sub rupture planes and several fractures were formed under $1 \mathrm{MPa} P_{\mathrm{c}}$ at $295 \mathrm{~K}$ (Fig. 5a). On the other hand, only one main rupture plane occurred at $353 \mathrm{~K}$ (Fig. $5 \mathrm{~b}$ ). The porosity at $353 \mathrm{~K}$ in the thin section analyses was $10.0 \%$ less in the region far from the rupture plane than that at $295 \mathrm{~K}$ (Fig. 5k). The rupture planes were absent in $15 \mathrm{MPa} P_{\mathrm{c}}$ cases and the porosity at $353 \mathrm{~K}$ was lower than that at $295 \mathrm{~K}$ by $4.63 \%$ (Fig. $5 \mathrm{k}$ ).

Under $1 \mathrm{MPa} P_{\mathrm{c}}$, far from the rupture plane, $0.14 \mathrm{~mm}$ and $0.10 \mathrm{~mm}$ equivalent diameter pores significantly decreased and $0.06 \mathrm{~mm}$ increased at $353 \mathrm{~K}$ (Fig. 5e). Under $15 \mathrm{MPa} P_{\mathrm{c}}$, significant decrease of $0.10 \mathrm{~mm}$ pores and increase of $0.06 \mathrm{~mm}$ pores were observed at $353 \mathrm{~K}$ (Fig. 5f). The frequency of aspect ratio 0.25 to 0.65 decreased at $353 \mathrm{~K}$ under $1 \mathrm{MPa}$ $P_{c}$ and 0.35 increased under $15 \mathrm{MPa} P_{\mathrm{c}}$ at $353 \mathrm{~K}$ (Fig. 5h). Pores parallel to the horizontal flow layer were dominant (Fig. 5i, j).

From the observations, it is obvious that pore collapse (Zamman et al. 1994) occurred during axial compression even under low confining pressures (Figs. 5 and 6) causing the permeability decrease. The highest permeability decrease under $15 \mathrm{MPa} P_{c}$ at $295 \mathrm{~K}$ was easily achieved even under $1 \mathrm{MPa} P_{\mathrm{c}}$ at $353 \mathrm{~K}$ (Fig. 5b) because of low porosity matrix due to enhanced pore collapse by thermal activation.

\subsection{Kimachi sandstone}

After 24 hours of consolidation, the permeability at $353 \mathrm{~K}$ under $>5 \mathrm{MPa} P_{c}$ was slightly lower than that at $295 \mathrm{~K}$ (Fig. 7a). During compression, permeability decreased first, began to increase before peak load, showed almost stable value at residual strength state (Fig. 7d). The minimum permeability decreased with confining pressure and no significant difference was observed between $295 \mathrm{~K}$ and $353 \mathrm{~K}$ (Fig. $7 \mathrm{~b}$ ). The post compression permeability decreased with confining pressure and the permeability at $353 \mathrm{~K}$ was slightly lower than that at $295 \mathrm{~K}$ (Fig. 7c).

For the specimens after 24 hours consolidation (Fig. 8a), the thickness of cementing materials decreased both by either confining pressure or temperature (Fig. 8b). The thickness at $353 \mathrm{~K}$ was smaller even under $1 \mathrm{MPa} P_{\mathrm{c}}$ than that under $15 \mathrm{MPa} P_{\mathrm{c}}$ at 295K.

In the post compression specimens, main and subrupture planes with several fractures were observed in the CT images under $1 \mathrm{MPa} P_{c}$ at $295 \mathrm{~K}$ (Fig. 9a).
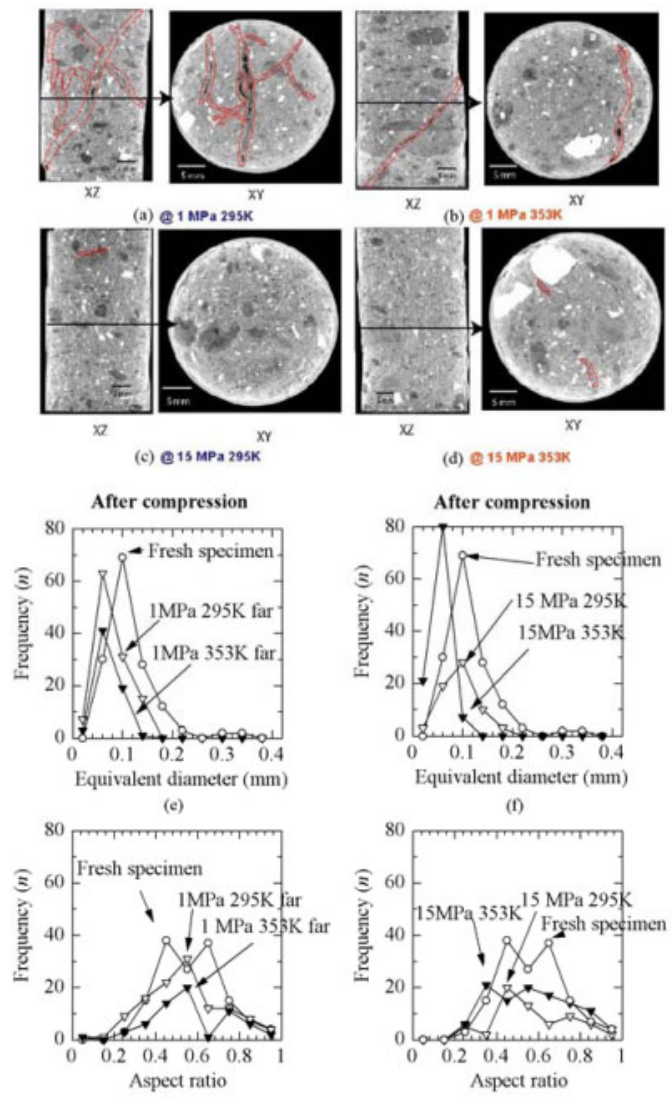

(g)

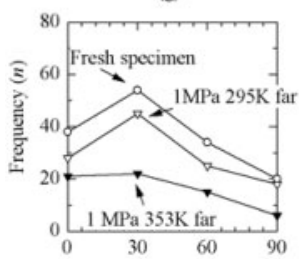

Angle of major axis (degree)

(i)

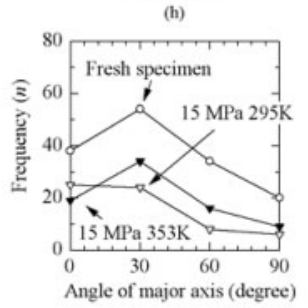

(j)

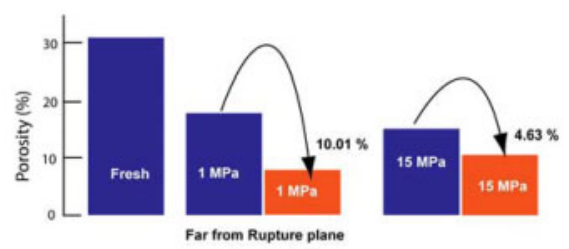

(k)

Figure 5. CT images and thin section image analyses of post compression specimens of Shikotsu welded tuff.

Only one main rupture plane with sub rupture plane was observed at $353 \mathrm{~K}$ (Fig. 9b). The average thickness of cementing material (Fig. 9g) for the specimen was $0.20 \mathrm{~mm}$ under $1 \mathrm{MPa} P_{c}$ at $295 \mathrm{~K}$ and $0.19 \mathrm{~mm}$ at $353 \mathrm{~K}$ of the thin section images (Fig. 9h). There were two rupture planes under $3 \mathrm{MPa} P_{\mathrm{c}}$ at $295 \mathrm{~K}$ (Fig. 9c) but only one in the case of 353K (Fig. 9d). The rupture planes were absent in the cases of $15 \mathrm{MPa} P_{c}$ 


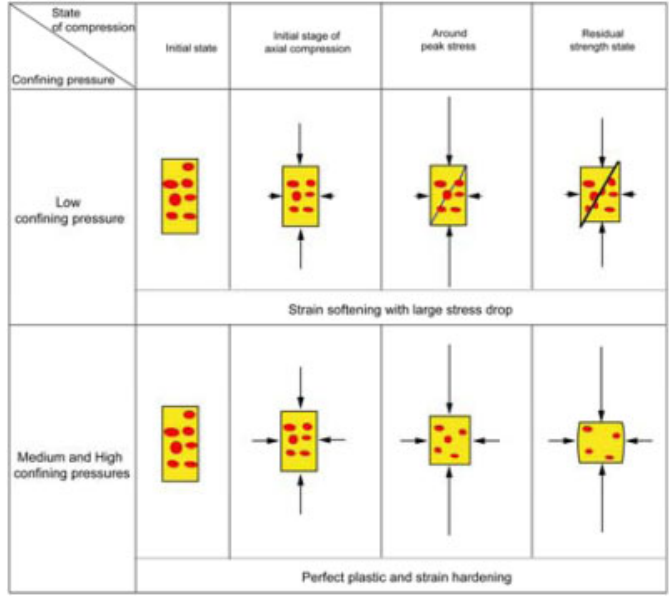

Figure 6. Confining pressure effects on structural changes of Shikotsu welded tuff.

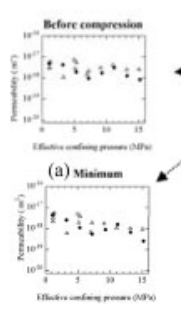

(b)

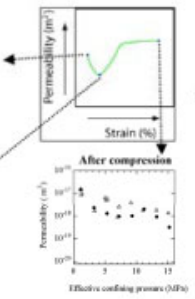

(c)

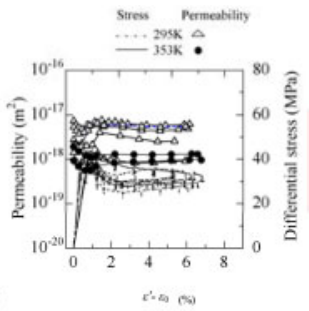

(d)
Figure 7. Permeability of Kimachi sandstone.

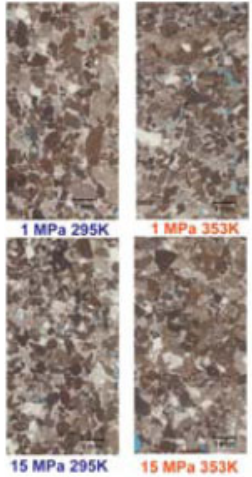

(a)

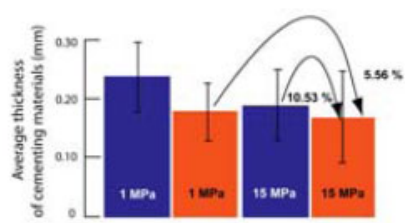

(b)
Figure 8. Thin section images and thickness of cementing materials of consolidated specimens of Kimachi sandstone.

(Fig. 9e, f). The average thickness of cementing material under $15 \mathrm{MPa} P_{\mathrm{c}}$ (Fig. $9 \mathrm{~g}$ ) was $0.15 \mathrm{~mm}$ at $295 \mathrm{~K}$ and $0.14 \mathrm{~mm}$ at $353 \mathrm{~K}$ (Fig. 9h).

From the observations, it can be considered that the decrease of permeability at consolidation and initial stage of axial compression was due to elastic as well as plastic closure of inclined microcracks (Alam et al. 2014) and its increase was due to nucleation and

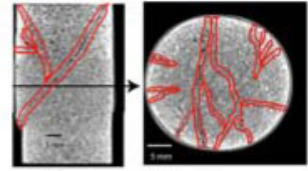

(a) $91 \mathrm{MPa} 295 \mathrm{~K}^{\mathrm{XV}}$

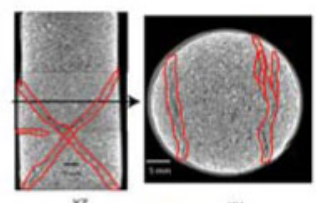

(c) es MPa 29sk

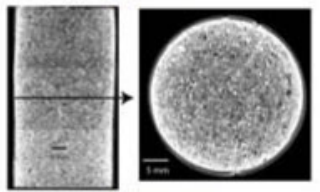

(e) a15 MPa 295K

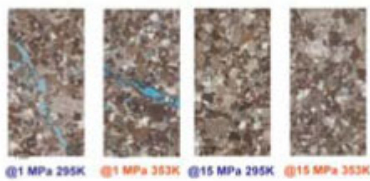

(g)

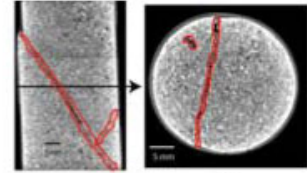

(b) ${ }^{x z}$ ermpassak

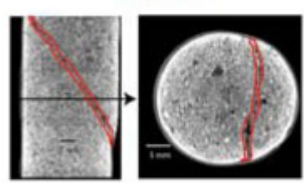

(d) ${ }^{x z} \operatorname{sapasax}^{x}$

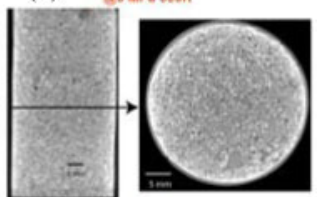

(f) ats upa asak

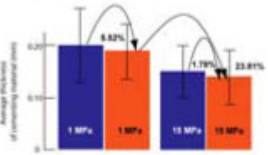

(h)
Figure 9. CT and thin section images and thickness of cementing materials of post compression specimens of Kimachi sandstone.

coalescence of microcracks (Kranz 1983) (Fig. 10). The decrease in number of rupture planes in the post compression specimens with confining pressures (Fig. 9, 10) was due to large plastic deformation of cementing materials. The post compression permeability at $353 \mathrm{~K}$ was slightly lower than that at $295 \mathrm{~K}$ (Fig. 7c) because of enhancement of the plastic deformation by thermal activation.

\subsection{Inada granite}

After 24 hour consolidation, the permeability at $353 \mathrm{~K}$ was lower than that at 295K (Fig. 11a). Permeability decreased, began to increase before peak load again and showed almost stable value under residual strength state during compression (Fig. 11d). The minimum permeability at $353 \mathrm{~K}$ was slightly lower than that at $295 \mathrm{~K}$ and the difference was larger in low confining pressures (Fig. 11b). The post compression permeability decreased with confining pressure up to $9 \mathrm{MPa} P_{\mathrm{c}}$ at $295 \mathrm{~K}$ or $7 \mathrm{MPa} P_{\mathrm{c}}$ at $353 \mathrm{~K}$, and increased afterward (Fig. 11c). Permeability at $353 \mathrm{~K}$ was significantly lower than that at $295 \mathrm{~K}$.

The decrease of permeability by consolidation with confining pressure was mainly due to elastic closure of inclined microcracks. This was not observed in the images as they were prepared after unloading. In the post compression specimen, under $1 \mathrm{MPa} P_{c}$ at $295 \mathrm{~K}$, there occurred one distinct thick main rupture plane with many sub rupture planes and fractures in CT 


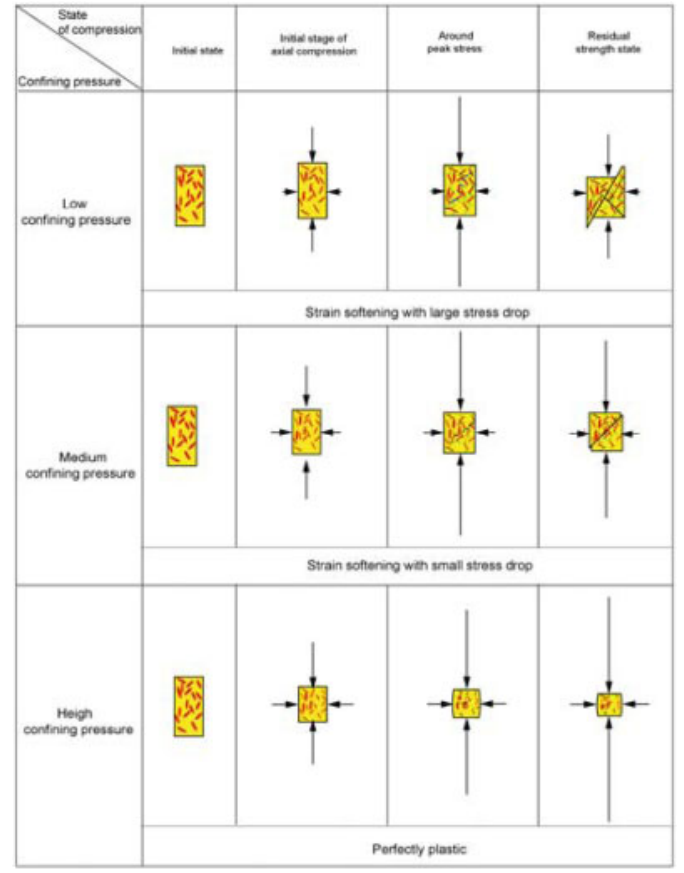

Figure 10. Confining pressure effect on structural changes of Kimachi sandstone.

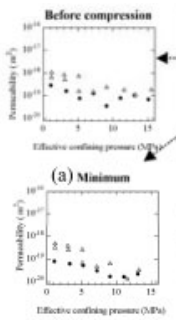

(b)

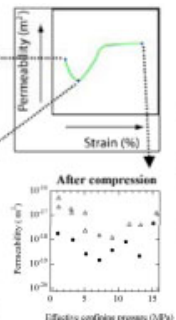

(c)

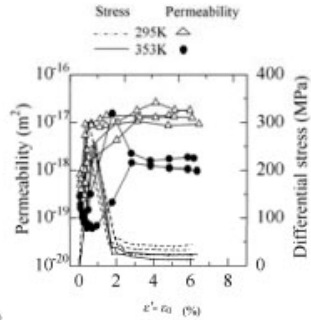

(d)
Figure 11. Permeability of Inada granite.

images (Fig. 12a). The rupture plane was the network of microcracks and there were axial cracks from biotite (Fig. 12c). Under $7 \mathrm{MPa} P_{c}$ at 295K, one main thin rupture plane was observed without the axial cracks from biotite (Fig. 12f). Two main rupture planes formed at $295 \mathrm{~K}$ under $15 \mathrm{MPa} P_{c}$ (Fig. 12h). One main thin rupture plane with subrupture plane (Fig. 12b,g) as well as elongation of biotite along the rupture plane (Fig. 12d, e) was observed for $1 \mathrm{MPa}$ and $7 \mathrm{MPa} P_{c}$ at $353 \mathrm{~K}$. Many subrupture planes and fractures formed under $15 \mathrm{MPa}$ at $353 \mathrm{~K}$ (Fig. 12i).

Several rupture planes and fractures caused the high permeability at $295 \mathrm{~K}$ under low confining pressures with axial cracks from biotite; Single rupture plane and absence of axial cracks from biotite caused the low permeability for medium confining pressure; Multi rupture planes caused the high permeability under high confining pressure (Fig. 12,13). The post compression permeability at $353 \mathrm{~K}$ was lower than that at
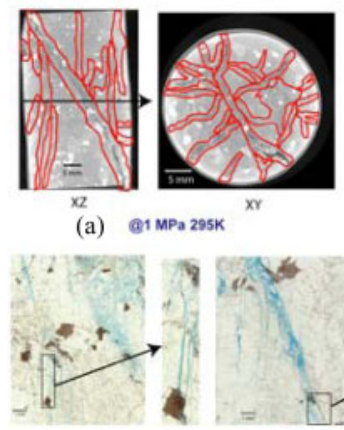

이 MPa 295K (c)

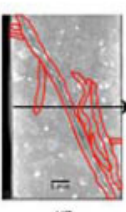

(f)

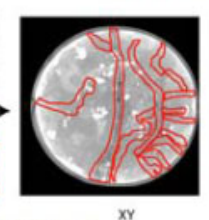

e7 MPa 295K

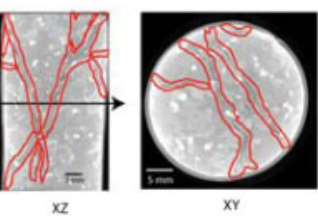

(h) $815 \mathrm{MPa} 295 \mathrm{~K}$

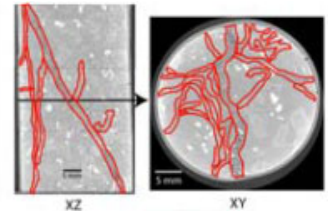

(b)

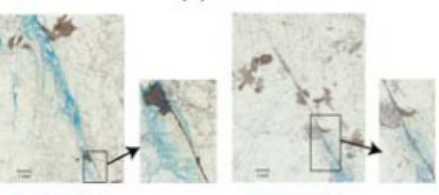

a7 MPa $353 \%$ (e) (a) $01 \mathrm{MPa} 295 \mathrm{~K}$

Figure 12. CT and thin section images of post compression specimens of Inada granite.

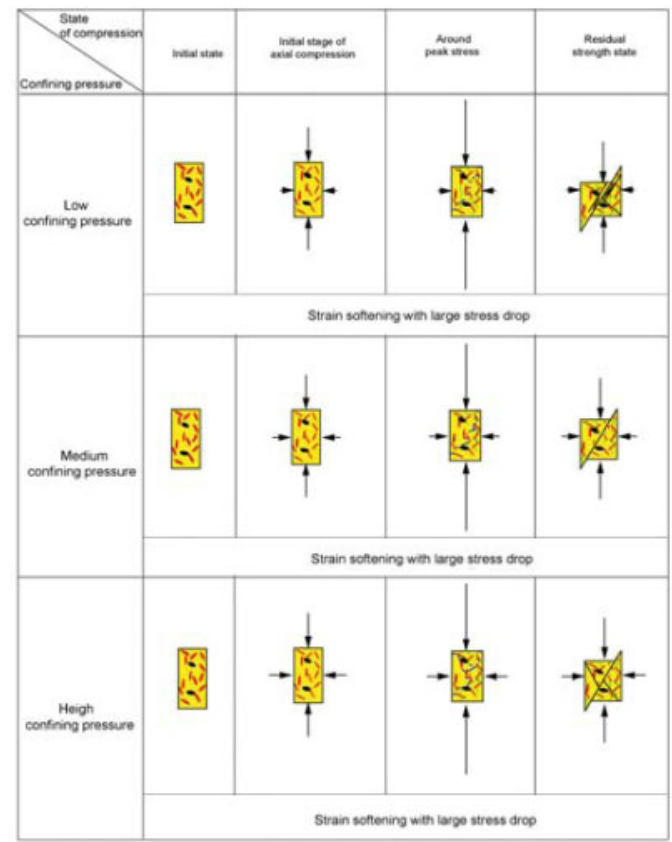

Figure 13. Confining pressure effect on structural changes of Inada granite. 


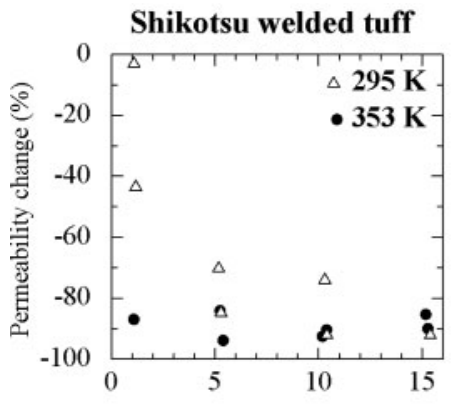

Effective confining pressure (MPa)

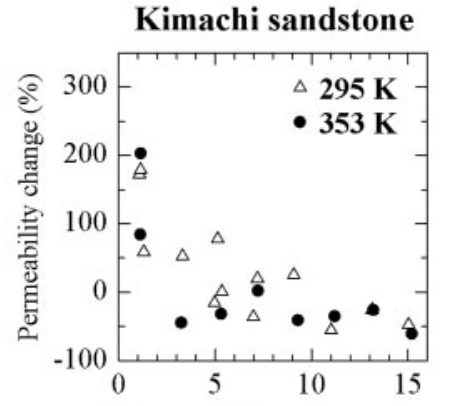

Effective confining pressure $(\mathrm{MPa})$
Inada granite

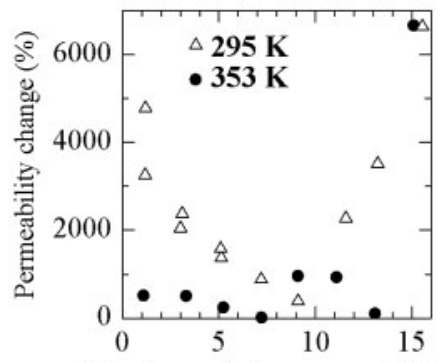

Effective confining pressure $(\mathrm{MPa})$

Figure 14. Permeability change due to failure.

295K (Fig. 11c) because of decrease in thickness of the main rupture plane, decrease of subrupture planes, fractures and the microcracks from biotite grains due to enhancement of viscous deformation of mineral grains by thermal activation (Fig. 13). The elongation of biotite along the rupture plane (Fig. 12d, e) was possibly another reason of the low permeability. The multi rupture planes under high confining pressures were caused by high stress concentration between the stiff rupture planes.

\section{PERMEABILITY CHANGE (Fig. 14)}

For Shikotsu welded tuff, the permeability decreased from consolidation to post compression by failure. The decreased ratio became larger with confining pressure from $2 \%$ to $92 \%$ at $295 \mathrm{~K}$. On the other hand, the ratio was from $84 \%$ to $94 \%$ and almost independent of confining pressure at $353 \mathrm{~K}$.

For Kimachi sandstone, the permeability at 295K increased by as high as $180 \%$ by failure under low confining pressures. It however decreased by as low as $47 \%$ under high confining pressures. The permeability at $353 \mathrm{~K}$ decreased by almost the same amount as that under $15 \mathrm{MPa} P_{\mathrm{c}}$ at $295 \mathrm{~K}$ except for $1 \mathrm{MPa} P_{\mathrm{c}}$.

For Inada granite at $295 \mathrm{~K}$, the permeability increased as high as $4780 \%$ by failure under $1 \mathrm{MPa}$ $P_{\mathrm{c}}$. The increase amount decreased until $9 \mathrm{MPa} P_{\mathrm{c}}$ to $394 \%$ and increased again up to $6640 \%$ at $15 \mathrm{MPa} P_{\mathrm{c}}$. At $353 \mathrm{~K}$, the permeability increase was as low as that under $9 \mathrm{MPa} P_{c}$ at $295 \mathrm{~K}$ and did not showed confining pressure dependency except for the result under $15 \mathrm{MPa} P_{\mathrm{c}}$.

\section{CONCLUSIONS}

Permeability of three types of rock under triaxial compression was measured at $295 \mathrm{~K}$ and $353 \mathrm{~K}$. The main findings are as follows.

(i) Permeability decreased monotonously for Shikotsu welded tuff. The permeability decreased first, began to increase before peak load and showed almost constant value in the residual strength state for Kimachi sandstone and Inada granite.

(ii) Permeability decreased by failure for Shikotsu welded tuff. It increased due to failure under low confining pressures but decreased under high confining pressures for Kimachi sandstone. It increased due to failure for Inada granite.

(iii) The permeability at $353 \mathrm{~K}$ was lower than that at $295 \mathrm{~K}$ for all of the three types of rock. The main mechanisms of the decrease were enhancement of pore collapse for Shikotsu welded tuff, plastic deformation of cementing materials for Kimachi sandstone and viscous deformation of mineral grains for Inada granite. Thermal activation acted for all of these mechanisms.

\section{ACKNOWLEDGEMENT}

This work was partly supported by KAKENHI (22560804). We are grateful to Professor Katsuhiko Kaneko (Laboratory of Terrestrial Engineering, Hokkaido University), for his kind help with the micro-focus X-ray CT scanner.

\section{REFERENCES}

Alam, A.K.M.B., Niioka, M., Fujii, Y., Fukuda, D. \& Kodama J. 2014 (In press). Effect of confining pressure on the permeability of three rock types under compression. Int J of Rock Mech Min Sci.

Hudson, J.A., Stephansson, O. \& Anderson, J. 2005. Guidance on numerical modeling of thermo-hydro-mechanical coupled processes for performance assessment of radioactive waste repositories. Int $J$ of Rock Mech Min Sci. 42: 850-870.

Kranz, R.L. 1983. Microcracks in rocks: A review. Tectonophysics 100:449-480.

Rutqvist, J., Barr, D., Datta, R., Gens, A., Millard, A., Olivella, S., Tsang, C-F. \& Tsang, Y. 2005. Coupled thermal-hydrological-mechanical analysis of the Yucca Mountain Drift Scale Test- Comparison of field measurements to predictions of four different numerical models. Int J of Rock Mech Min Sci. 42: 680-697.

Zaman, M., Roegiers, J.-C., Abdulraheem, A. \& Azeemuddin, M. 1994. Pore collapse in weakly cemented and porous rocks. J of Energy Resources Tech 116:97-103. 